\title{
Conceptualization of the Subjective Image of Adulthood in the Semantic Space of a Linguistic Personality
}

\section{Концептуалізація суб'єктивного образу дорослості у семантичному просторі мовної особистості}

\author{
Natalya Tokareva ${ }^{1}$ \\ Dr. in Psychology, \\ Associate Professor, \\ Head of Common and \\ Age Psychology Faculty
}

\author{
Наталя Токарева ${ }^{1}$ \\ доктор психологічних наук, \\ доцент, \\ завідувач кафедри загальної \\ та вікової психології
}

\section{E-mail: tokareva152681@gmail.com https://orcid.org/0000-0003-1428-3729 \\ ResearcherID: G-8396-2019}

\section{Anzhelika Shamne ${ }^{2}$ \\ Dr. in Psychology, Associate Professor}

\author{
Анжеліка Шамне 2 \\ доктор психологічних наук, \\ доцент
}

\section{E-mail: shamne@ukr.net https://orcid.org/0000-0003-1541-6079 \\ ResearcherID: S-5684-2019}

\author{
${ }^{1}$ Kryvyi Rih State \\ Pedagogical University \\ 54, Gagarin Av., Кгуvуi Rih, \\ Dnepropetrovsk Reg., \\ Ukraine, 50027
}

${ }^{2}$ National University of Life and Environmental Sciences of Ukraine $\bowtie$ 10, Heroyiv Oborony Str., Kyiv, Ukraine, 03127
${ }^{1}$ Криворізький державний педагогічний університет

$\checkmark$ пр. Гагаріна, 54, Кривий Ріг, Дніпропетровська обл., Україна, 50027

${ }^{2}$ Національний університет біоресурсів $i$ природокористування України $\triangle$ вул. Героїв оборони, 10, Київ, Україна, 03127 
Кониептуалізація суб’єктивного образу дорослості...

\section{ABSTRACT}

Introduction. The article is devoted to the analysis of the problem of cognitive-semantic modelling of the subjective image of adulthood by schoolchildren of adolescence in modern sociocultural space. The authors proved that the logical-meaningful constructs of the linguistic picture of the world explicate the sociolect of the subjects of speech and form the conceptual space of the mental continuum, which is especially important for rethinking the semantic indicators of a personality formation in the process of growing up. The image of adulthood is interpreted by the authors as the most personalized systemic structure, which reflects the representation of the subjects of linguistic consciousness about the ideal self in the temporal perspective.

Research procedure. The research procedure involved the use of conceptual analysis methods, analysis of vocabulary definitions, content analysis. Based on the results of 4207 text fragments and respondents' answers study, quantification units of the semantic field of the studied conceptosphere, the core (semantic constant) and the peripheral part (its information-content and interpretation segments) were identified.

Results. Empirically, the characteristics of the conceptual linguization were clarified to indicate the phenomenon of adulthood in the semantic space of the linguistic personality, the psycholinguistic features of the linguistic objectification of the concepts Adult and Becoming an Adult were identified in the consciousness of the subjects of ageing, and trends in the age-related dynamics of the cognitive-semantic nature of the adult concept in the minds of schoolchildren were specified. It has been stated that in the formatting of the subjective image of adulthood by schoolchildren of adolescence, there is a transition from empirical identification and awareness of predominantly "external» attributes of adulthood to a generalization of the internal relevant subsystems for assessing the world, oneself and other people (primarily adults). It is statistically confirmed that the main transformations of the subjective image of adulthood in the semantic space of the linguistic personality occur in adolescence, which should be the object of corrective and preventive interventions in the dynamic context of the psychological support of growing up.

Conclusions. The results obtained substantially complement the materials presented by the scientific community on the trends in the conceptualization of the indicators of modern youth growing up.

Key words: image of adulthood, linguistic picture of the world, linguistic personality, adolescence, conceptual sphere, semantic-cognitive model, logical-meaning construct, semantic field.

\section{Вступ}

Глобальні трансформаційні процеси сучасності, нестримність i суперечливість інформаційної епохи постмодернізму у XXI столітті спричинили полімодальність та безперервну 
варіативність хронотопу універсальної матриці світоустрою. Динамізм, відкритість реального контенту життєтворчості людства, пролонгованість ситуації невизначеності у генезі буття суттєво позначилися на специфіці моделювання картини світу як вихідного глобального образу, покладеного в основу світогляду людини, що репрезентує сутнісні властивості світу у розумінні його носіїв і $€$ результатом всієї духовної активності людини (Постовалова, 1988). Метафорично позначене свідомістю відображення світу людини нового покоління (Internet-покоління, сповненого потенційними ресурсами ствердження своєї «інакшості») декларує еклектику світосприймання, відмову від догматів минулого, зумовлює фрагментарність Я-концепції й норми поведінки.

Картина світу людини може бути експлікована у різних формах i різними засобами, виключна роль серед яких належить мові як особливому коду концептуалізації та пізнання світу, про що свідчать дослідження вчених (Блох, 2010; Воркачев, 2001; Жайворонок, 2004; Лисиченко, 2009; Рогожнікова, 2008; Цейтлин, 2018; Evans, 2006; Nelson, 1973; Taylor, 2003) й інших науковців, котрі працюють у парадигмі інтегративного синтезу наукових концептів психолінгвістики, онтолінгвістики, когнітивної лінгвістики, лінгвокультурології. На основі цілісної лексико-семантичної системи мови, формалізованої у комплексі знань, надбаних завдяки власному і суспільному досвіду мовної особистості, свідомістю людини продукується «концептуально-мовний універсум» (Жайворонок, 2004: 26) - мовна картина світу; відображені у ній логіко-смислові конструкти, предметні, предикатні, модальні, дискурсивні та інші «кванти» значення (цит. за: Радзієвська, 2010: 8) складаються у цілісну єдність (своєрідну колективну філософію, що є проекцією соціолекту суб'єктів мовлення), яка утворює концептуальний простір ментального континууму. Загальні тенденції функціонування мовної картини світу в цілому та семантичного розвитку іiі окремих компонентів (зокрема, концептів та концептосфер) активно вивчаються науковцями у проблемному полі лінгвістики i психолінгвістики (Воркачев, 2014; Гоменюк, 2015; Городецька, 2002; Лисиченко, 2009; Радзієвська, 2010 та ін.). Разом з тим, нам видається переконливою думка професора Т.М. Рогожнікової, яка у контексті аналізу динамічних аспектів значення слова у вимірах буття людини наголошує, що світова наука все частіше приходить 
Кониептуалізація суб’єктивного образу дорослості...

до визнання недоцільності подальшого ігнорування відмінностей між значенням, котре описується із позицій логіко-раціонального підходу, i значенням, яке реально функціонує у свідомості людини (Рогожнікова, 2008: 209-210).

Аналіз наукової літератури доводить, що проблема розвитку й розуміння значення слова у індивідуальній свідомості в умовах норми займає вагоме місце у площинах наукової дискусії (Воркачев, 2001; Калмикова, 2003; Постовалова, 1988; Протасова, Родина \& Васюкова, 2011; Рогожнікова, 2008; Токарева, 2015; Kharchenko, 2017 та інші). Адже слово у психолінгвістиці трактується як одиниця ментального лексикону людини i засіб доступу до єдиної інформаційної матриці людства - складного продукту перцептивно-когнітивно-афективного опрацювання особистістю полімодального досвіду пізнання i спілкування. Усвідомлення сутності функціонування слова у семантичному просторі суб'єкта мовлення дотичне проблематиці організації і структурування мовної свідомості людини, що обумовлює актуальність дослідницького інтересу до психологічних особливостей моделювання мовної картини світу людини в умовах несталого соціокультурного середовища. У вимірах онтолінгвістики (First Language Acquisition) науковці (Протасова, Родина \& Васюкова, 2011; Цейтлин, 2018; Evans, 2006; Nelson, 1973 та ін.) наголошують, що оволодіння мовою, а отже й формування дитиною власної мовної системи, пов'язано із дорослішанням і розвитком дитини (Цейтлин, 2018: 17). Водночас онтогенетичний ракурс проблеми розгортання концептуальної сфери мовлення у свідомості мовної особистості підлітково-юнацького віку залишається у психолінгвістиці маловивченим.

Особливої уваги науковців потребує період зростання (дорослішання) дитини, протягом якого особистісні пошуки моделі «дорослого» життя набувають усвідомлюваного характеру, означують ускладнення системи уявлень про себе, ієрархізацію самооцінок на основі перших спроб самоаналізу, порівняння себе 3 іншими (i перш за все - iз дорослими). Вагомим атрактором психічного розвитку особистості на етапі дорослішання $\epsilon$ образ дорослості (Зоріна, 2017; Чернобровкіна, 2015 та ін.): він впливає на цілепокладання, осмислення програм самовиховання, розвиток персонологічних конструктів, виявлення активної життєвої позиції й суб'єктності, обумовлює форматування системи соціальної 
поведінки підлітків та юнацтва (Зоріна, 2017; Токарева, 2015; Arnett, 2007; Massoglia \& Uggen, 2010; Shamne, 2013 та ін.).

Не потребує доведення той факт, що динамічне інформаційне сьогодення висуває надвисокі вимоги до вимірів соціалізації та моделювання «дорослої поведінки» дитини, проте недостатність шляхів інтеріоризації соціального досвіду, «нечіткий» образ дорослості у свідомості дитини перешкоджають адекватному засвоєнню сценаріїв дорослості підлітками та юнацтвом. Форматування образу дорослості у суб'єктів дорослішання часто поєднується із категоричністю і прямолінійністю оцінок, демонстративним негативізмом i моральним скептицизмом; ідентифікаційні стратегії поведінки дітей є також відображенням інтелектуальних і моральних пошуків, прагненням переосмислити істини i прийняти їх не як нав'язані 3зовні, а як самостійно відформатовані й змістовні. У площині означеного вважаємо доведеною актуальність переосмислення семантичних індикаторів (у тому числі й концептів, котрі втілюються у персонологічних картинах світу) особистісного становлення людини у вимірах сучасного суспільства.

Метою даної розвідки ми вважали виявлення психологічних особливостей мовної об'єктивації концептосфери на позначення феномену дорослості у свідомості суб'єктів дорослішання в сучасному соціокультурному середовищі.

Кониептосферу розглядаємо як складно структурований асоиіативною множиною конщептів когнітивно-семантичний простір мовної особистості, щзо відображує усвідомлюваний $i$ вербалізований певний фрагмент дійсності у вимірах ментальної картини світу.

Концептосфери, як наголошує професор М.Я. Блох, «можуть бути представлені у вигляді фреймів - номенклатурних схем, щуо поєднують об'єктивний $i$ суб'єктивний контенти картини світу людини, адже відображують об'єктивний світ крізь призму суб'єктивного світосприймання» (Блох, 2010: 39).

Відповідно, у мовних конструктах свідомості категоризуються не лише об'єкти фізичного світоустрою, але й суб'єктивні образи (складні системи соціальних уявлень людини), що 
Кониеептуалізація суб'єктивного образу дорослості...

«спираються на культурні традиції, інституційні цінності, вимоги соціуму $і$ суб'єктивний життєвий досвід» (Андреева, 2018: 6)

й концептуалізують інтелектуальний, соціальний, соціокультурний потенціал особистості у вимірах життєтворення; означене, на наш погляд, $€$ надзвичайно важливим фактором організації кваліфікованого психологічного супроводу особистості у період дорослішання.

\section{Методи та методики дослідження}

Континуум вивчення психологічних особливостей концептуалізації суб’єктивного образу дорослості у семантичному просторі мовної особистості декларує вимоги до коректного формування вибіркової когорти даного емпіричного дослідження. Зважаючи на закономірності вікового розвитку особистості, беззаперечною $\epsilon$ значимість моделювання змісту концептосфери на позначення феномену дорослості у мовній свідомості школярів підлітково-юнацького віку, коли усезагальною формою розвитку стає дорослішання, а головною життєво-смисловою задачею відкриття меж між ідеальною та реальною формами дорослості (Shamne, 2013). Процес такого «відкриття» (як взаємодії між концептами ідеальної та реальної формами дорослості у картині світосприймання суб'єкта дорослішання, у контексті якої «дорослий» є не просто «образом іншого», але й проекцією себе через іншого) втілюється у специфічних змінах самосвідомості особистості, пов'язаних із орієнтуванням у соціально заданих зразках дорослості та актуалізацією образу дорослості у свідомості: засвоєнні (і прийнятті на пізнавальному і потребово-мотиваційному рівнях) суттєвих рис дорослості як власного майбутнього, своєрідного «акцептора результату» подальшого особистісного становлення. У площині означеного вибірку дослідження склали 732 особи 10-17 років (учні 5-11 класів загальноосвітніх шкіл м. Кривого Рогу (Україна)). 3 метою більш повного означення загальної динаміки досліджуваного феномену цільова вибіркова сукупність була доповнена респондентами молодшого шкільного віку (57 учнів початкової школи віком 7-9 років), відповіді яких 
інтерпретувалися нами як семантико-когнітивна модель презентації суб'єктивного образу дорослості у генезі дитинства, та студентами стаціонарної і заочної форм навчання Криворізького державного педагогічного університету віком 20-27 років (72 особи), відповіді яких розглядалися нами як модель концептосфери на позначення феномену дорослості у семантичному просторі дорослої мовної особистості. Матеріалом дослідження стали 4207 відповідей i текстових фрагментів респондентів.

Інтегративний контент предметного поля даного психолінгвістичного дослідження обумовив структурування логіки дослідницької програми у площині реалізації генетичного методу системних досліджень, котрий стверджує необхідність аналізу способів породження психічних утворень, закономірностей їх трансформацій, співвіднесення актуального i потенційного у психічному розвитку; даний метод покликаний забезпечити осмислення певного сегменту реальності як складного утворення, що функціонує під впливом сукупності об'єктивних i суб'єктивних факторів i, у свою чергу, активно впливає на них. Онтологічним референтом системно-інтегративного підходу до аналізу особливостей генези концептуалізації суб'єктивного образу дорослості у семантичному просторі мовної особистості, що дозволяє експлікувати, усвідомити і реконструювати семантичне поле репрезентації суб'єктних можливостей 3 метою оптимізації вимірів суб'єктогенезу, можна вважати конвергенцію трьох векторів дослідження:

- уточнення особливостей лінгвалізації концептосфери на позначення феномену дорослості у семантичному просторі мовної особистості;

- дослідження психолінгвістичних

особливостей концептуалізації суб'єктивного образу дорослості школярами підлітково-юнацького віку, що задовольняють певним вимогам до формування особистісних конструктів в умовах сучасного соціокультурного середовища;

- означення тенденцій вікової динаміки когнітивносемантичної природи концептосфери дорослості у свідомості школярів.

На етапі визначення особливостей лексико-семантичного структурування концептосфери на позначення феномену дорослості 
Кониептуалізація суб’єктивного образу дорослості...

нами був застосований метод концептуального аналізу (Полюжин, 2005 та ін.), ресурсний потенціал котрого передбачає моделювання та опис відповідної концептосфери i $\epsilon$ одним із засобів комплексної реконструкції когнітивних механізмів індивідуальної та/або колективної свідомості, які опосередковують формування i упорядкування мовної картини світу особистості. Залучення методу концептуального аналізу до психолінгвістичного континууму детермінує не лише означення смислів досліджуваних концептів, а й констатацію специфіки концептуального поля і логічних відношень між його елементами.

Об'єктивну інформацію про концептосферу на позначення феномену дорослості нами було отримано у словниках, а тому були використані окремі елементи методу аналізу словникових дефініцій.

Специфіка дослідження суб'єктивного образу дорослості (як нової форми самосвідомості у генезі підлітково-юнацького віку) у семантичному просторі мовної особистості ускладнювалася недостатньою рефлективністю даного феномену, а отже необхідністю опосередкованого дослідження. Для досягнення мети i виконання поставлених завдань щодо особливостей інтеріоризації концептосфери дорослості у свідомості суб'єктів дорослішання нами були використані методи і психодіагностичні методики, адекватні предмету дослідження:

- анкета (із запитаннями відкритого типу), зорієнтована на виявлення усвідомлюваних та неусвідомлюваних тенденцій розгортання образу дорослості, що репрезентує особливості розвитку когнітивно-семантичного компоненту мовної свідомості особистості в період переходу від дитинства до дорослості (у контексті становлення нової форми самосвідомості);

- модифікований варіант нестандартизованого самозвіту («Хто Я?») із подальшим контент-аналізом, розроблений M. Куном та Т. Мак-Партландом (модифікований Т.В. Румянцевою), що використовується для вивчення змістовних характеристик ідентичності (особистісної рефлексивності) особистості (цит. за: Токарева, 2015: 223);

- методика вільного (наративного) опису «Ідеальний світ дорослих», що надає можливість означити психологічно 
значущі структури когнітивно-семантичної природи концептосфери дорослості у свідомості респондентів.

Первинна обробка даних здійснювалася методом контент-аналізу із подальшим ранжируванням значущості номінативних блоків та обчисленням статистичних значень отриманого матеріалу. Були використані критерій КолмогороваСмірнова ( $\lambda$ ), що дозволяє означити статистичні відмінності отриманих даних від нормативного розподілу отриманих даних у семантичному полі концептосфери дорослості, та, задля підтвердження значимості отриманих даних, метод рангових кореляцій Спірмена (Rs).

При узагальненні та аналізі емпіричних матеріалів була використана комп'ютерна статистична програма IBM SPSS Statistics 19 («Statistical Package for the Social Science» статистичний пакет для соціальних наук). Змінні були перевірені на нормативність розподілу ознаки.

\section{Результати та дискусії}

Побудова номінативного поля концептосфери на позначення феномену дорослості у семантичному просторі мовної особистості у межах даного дослідження була зорієнтована на встановлення та опис сукупності значень мовних засобів, що номінують ключовий концепт (як форму схематичної репрезентації знань про об'єкти дійсності та результати внутрішнього рефлексивного досвіду у свідомості людини) та його окремі ознаки. Разом 3 тим, метод концептуального аналізу обумовлює осмислення структури вербалізованого концепту, виокремлення ядра (семантичної константи) й периферійної частини досліджуваної лексеми.

Аналіз представлених у лексикографічних джерелах, таких, як «Словник української мови» (Білодід, 1971), «Краткий психологический словарь» (Петровский \& Ярошевский, ред., 1998 та ін.) номінацій різновидів денотату концептів, що входять до концептосфери на позначення феномену дорослості, фіксує дві найбільш поширені лексеми: іменник Дорослий і дієслово Доростати, ядро котрих формується двома складниками: (1) який перестав бути дитиною, змужнів та (2) який досяг зрілості (певного 
рівня, віку). Когнітивно-семантичний контент ядерного сегменту досліджуваної концептосфери (семантична константа) забезпечує об'єктивацію абстрактних індикаторів дорослості у вимірах мовної свідомості із картиною світу носіїв мови. Синонімічний ряд концептів даного семантичного поля представлений лексемами змужнілий, зрілий, старший та ставати дорослим, дозрівати; антонімічні зв'язки досліджуваної концептосфери означені дихотомією Дорослий - Дитина.

Структура периферійної частини досліджуваного концепту (семантичний контент котрої відображує суб'єктивний досвід використання концепту у соціокультурному вимірі функціонування мовної свідомості) складається із інформаційно-змістового та інтерпретаційного елементів.

Інформаційно-змістовий контент («мовна фіксація концепту» (Мартинюк, 2006)) містить комплекс когнітивних ознак, значимих для розгортання семантичного простору слова i концептуалізації предметів або явищ світоустрою певною лінгвокультурною групою (означення концепту, опис, ознакова структура, дефініція тощо); у площині даного дослідження ми акцентували увагу, зокрема, на презентації феномену дорослості у науковому доробку фахівцівпсихологів. Було виявлено, що концепт Дорослість тлумачиться науковцями переважно як (1) період онтогенезу, пов'язаний із досягненням найвищого рівня розвитку духовних, інтелектуальних $i$ фізичних здібностей особистості (див.: Краткий психологический словарь, 1998) та (2) образ дорослості - особлива проекція ідеальної форми, що означує цілісність дитинства (його культурних рис) і $є$ основним способом й орієнтиром для презентації дітьми їх майбутнього (Выготский, 1984; Зоріна, 2017; Чернобровкина, 2015; Arnett, 1997; Arnett, 2007; Gurba, 2008; Massoglia \& Uggen, 2010; Shamne, 2013 та ін.). Серед характеристик дорослої (зрілої) особистості дослідники переважно називають відповідальність, потребу у піклуванні про інших, активну життєву позицію, здатність до конструктивного вирішення життєвих проблем на иляху до самореалізаиії (Петровский \& Ярошевский, 1998).

Інтерпретаційний сегмент структури периферійної частини номінативного поля концепту Дорослість фіксує когнітивні ознаки та інтерпретаційні схеми суб'єктивного досвіду носіїв мови у площинах індивідуального моделювання у мовній свідомості 
прагматичних елементів лексем, конотацій, асоціацій (як мовних репрезентацій ключових когнітивних ознак), спрямованих на позначення феномену дорослості.

У площині дослідницької програми даної статті виявлення особливостей реального вживання мовних одиниць семантичного поля концептосфери на позначення феномену дорослості було здійснено авторами на підставі аналізу мовної об'єктивації (або концептуалізаціі) суб'єктивного образу дорослості у свідомості школярів підлітково-юнацького віку (за термінологією А.В. Шамне (Shamne, 2013)). У даному контексті образ дорослості визначається як максимально персоналізована системна структура, котра відображує уявлення суб'єктів мовної свідомості про ідеального себе у часовій перспективі (Зоріна, 2017: 143).

Дослідженню підлягали процес і результат концептотворення як «форми вербалізації певного понятійного змісту» (Воркачев, 2001: 17-18) шляхом збагачення та/або розширення семантичної константи відповідного концепту.

Гіпотеза емпіричного дослідження означила припущення щодо значущості відмінностей концептуалізації суб'єктивного образу дорослості у мовній свідомості суб'єктів дорослішання різного віку.

Моделі специфічних способів концептуалізації феномену дорослості дітьми (на прикладі молодшого шкільного віку) й дорослими (на прикладі студентського періоду генези буття) інтерпретувалися нами як еталони співвідношення зовнішніх та внутрішніх детермінант моделювання мовної картини світу (зокрема й представлення у мовній свідомості концептів певної семантики). Процес рекомбінації компонентів системи детермінант концептуалізації як вторинного переосмислення (Мартинюк, 2006) і модифікації відповідної лексеми в період переходу від дитинства до дорослості був операціоналізований нами у формі констатації змінюваності в онтогенезі співвідношення зовнішніх та внутрішніх критеріїв оцінювання суб'єктом дорослішання світу, себе самого, інших людей (передусім, дорослих).

У процесі дослідження вивчалися відповіді респондентів на питання анкети (наприклад: «Чим, на ваш погляд, діти відрізняються від дорослих?», «Які риси ви вважаєте найбільш важливими для характеристики дорослої людини?», «Що означає, на ваш розсуд, твердження «стати дорослим», про які зміни 
Кониептуалізація суб’єктивного образу дорослості...

йдеться?»), а також когнітивно-семантичні характеристики (конструали) суб'єктивного образу дорослості, представлені у текстах нестандартизованого самозвіту («Хто Я?») і вільного наративного опису «Ідеальний світ дорослих». Зібраний матеріал ми трактували як інтерпретаційний сегмент структури периферійної частини номінативного поля концепту Дорослість, що являє собою сукупність слабко структурованих предикацій, котрі відображають інтерпретацію окремих концептуальних ознак та їх сполучень у вигляді видових номінацій семантичної константи досліджуваного концепту, сентенцій, які випливають у культурі даної вікової групи зі змісту концепту.

Контент-аналіз отриманих даних дозволив означити одиниці квантифікації семантичного поля досліджуваної концептосфери й виділити базові конструкти (індикатори аналізу). Узагальнені результати психодіагностичного вимірювання тенденцій моделювання суб'єктивного образу дорослості у порівнюваних групах вибіркової сукупності наведені у таблиці 1.

Таблиця 1. Рангові місця конструктів образу дорослості в групових ієрархіях респондентів

\begin{tabular}{|c|c|c|c|c|c|c|}
\hline \multirow{3}{*}{$\begin{array}{l}\text { Базові } \\
\text { конструкти }\end{array}$} & \multicolumn{6}{|c|}{ Вікові групи респондентів } \\
\hline & $\begin{array}{c}7-9 \\
\text { років } \\
(\mathrm{N}=57)\end{array}$ & $\begin{array}{c}10-11 \\
\text { років } \\
(\mathrm{N}=296)\end{array}$ & $\begin{array}{c}12-13 \\
\text { років } \\
(\mathrm{N}=255)\end{array}$ & $\begin{array}{c}14-15 \\
\text { років } \\
(\mathrm{N}=121)\end{array}$ & $\begin{array}{c}\text { 16-17 } \\
\text { років } \\
(\mathrm{N}=60)\end{array}$ & $\begin{array}{c}20-27 \\
\text { років } \\
(\mathrm{N}=72)\end{array}$ \\
\hline & \multicolumn{6}{|c|}{ Рангові місця конструктів } \\
\hline Зовнішність & 2 & 2 & 3 & 6 & 6 & 9 \\
\hline Робота, сім’я & 1 & 3 & 7 & 10 & 11 & 8 \\
\hline Інтелектуальні властивості & 3 & 1 & 1 & 2 & 3 & 5 \\
\hline Відповідальність & 7 & 5 & 2 & 3 & 2 & 3 \\
\hline Автономність & 10 & 8 & 10 & 5 & 7 & 4 \\
\hline Життєвий досвід & 8 & 6 & 5 & 1 & 1 & 1 \\
\hline Особистісні характеристики & 6 & 7 & 6 & 4 & 4 & 2 \\
\hline Життєві перспективи & 12 & 12 & 12 & 8 & 9 & 7 \\
\hline Поведінкові схеми & 4 & 4 & 4 & 7 & 5 & 11 \\
\hline Екзистенційні цінності & 13 & 13 & 13 & 9 & 8 & 6 \\
\hline Компетенції & 5 & 9 & 9 & 11 & 10 & 10 \\
\hline Емоційно-ціннісні оцінки & 11 & 10 & 8 & 12 & 11 & 11 \\
\hline Інше & 9 & 11 & 11 & 13 & 11 & 12 \\
\hline
\end{tabular}


(1) Аналіз когнітивно-семантичних характеристик і рангових позицій конструктів суб'єктивного образу дорослості респондентів засвідчив суттєві зміни у віковій динаміці концептотворення. Звертає на себе увагу, передусім, динаміка змінюваності співвідношення зовнішніх (доступних спостереженню) i внутрішніх (пов'язаних із внутрішнім світом) індикаторів оцінювання дитиною концептів Дорослий і Дорослішати (доростати), зафіксованих в одиницях мови. Так, молодші підлітки 10-11 років дотримуються переважно дитячої моделі концептуалізації образу дорослості (їх ранговий профіль близький до профілю респондентів молодшого шкільного віку), зосереджуючись на когнітивно-семантичних ознаках зовнішнього профілю: зовнішність, соціальні ролі (робота, сім'я), поведінка; хоча вагоме місце (1 рангова позиція) в образі дорослого для молодших підлітків відіграє інтелект («Дорослі більше знають», «Вони розумніші»). В цілому ж семантичне поле концептосфери на позначення феномену дорослості у картині світу дітей і молодших підлітків розгортається навколо дихотомії Дорослий - Дитина й означує перспективи дорослішання.

Старші підлітки 14-15 років й старшокласники періоду ранньої юності (16-17 років) у процесі концептуалізації образу дорослості більш зорієнтовані на дорослу модель виявлення даної концептосфери (про що свідчить частотність вживання ними лексем смислового поля інформаційно-змістових структур периферійного сегменту образу дорослості й означення ресурсного потенціалу суб'єктності). Концепт Дорослий респондентами даної групи окреслений переважно ознаками внутрішнього профілю: життєвий досвід («Вони більше прожили, більше бачили»), відповідальність («Дорослі мають виховувати дітей», «Вони відповідальні за свої вчинки») та інтелектуальні властивості («Дорослі здатні вирішувати складні задачі», «Можуть приймати важливі рішення»). Дані тенденції ще більше посилюються у семантиці вираження та об’єктивації суб'єктивного образу дорослості студентами.

Якісний аналіз емпіричного матеріалу дозволяє констатувати, що у віковій динаміці відповіді стають все більш розгорнутими та диференційованими; із 14-15 років у мовленнєвих сентенціях підлітків спостерігається помітне зростання абстрактності (зокрема, частіше використовується лексема Дорослість та іiі номінативні означення), лаконічності, обгрунтованості відповідей. 
Кониептуалізація суб’єктивного образу дорослості...

Подальший аналіз емпіричного матеріалу був здійснений із використанням критерію $\lambda$ Колмогорова-Смірнова, який дозволяє виявити період накопичення в динаміці змін, в межах котрого сума накопичених відмінностей $\left(\mathrm{d}_{\max }\right)$ між оцінками різних вікових груп буде максимальною. Отримане значення $d_{\max } \epsilon$ в нашому випадку операціоналізованим показником появи у старших вікових групах нового типу семантичних значень (суттєво більших або менших) порівняно із попередніми віковими періодами, а отже - i появи якісно нових форм оцінки образу дорослості в онтогенезі. Критерій $\lambda$ Колмогорова-Смірнова статистично підтвердив відмінності отриманих даних від нормативного розподілу відповідей у семантичних полях конструктів «Робота, сім'я» (тенденція зменшення використання: $d_{\max }$ зафіксовано в показниках молодших підлітків $\left(\mathrm{d}_{\max }=0,248\right.$ при $\left.\left.\mathrm{p}<0,01\right)\right)$ та «Компетенції»: dmax зафіксовано у відповідях молодших школярів $\left(\mathrm{d}_{\max }=0,195\right.$ при $\left.\mathrm{p}<0,05\right)$. Зафіксовано відмінності у семантичному контенті параметрів «Зовнішність» (тенденція до зменшення показників) і «Автономність» (тенденція до збільшення кількості конструалів даного типу): точка найбільшого акумулювання розходжень у них - старший підлітковий вік (відповіді підлітків 14-15 років): $\mathrm{d}_{\max }$ дорівнює відповідно 0,187 і 0,218 (при $\mathrm{p}<0,01$ ). Достовірно відрізняється від теоретичного розподіл відповідей у категоріях «Відповідальність» $\left(\mathrm{d}_{\max }=0,215\right.$ при $\left.\mathrm{p}<0,01\right)$, «Життєві перспективи» $\left(\mathrm{d}_{\max }=0,333\right.$ при $\left.\mathrm{p}<0,01\right)$, «Життєвий досвід» $\left(\mathrm{d}_{\max }=0,28\right.$ при $\mathrm{p}<0,01)$, в яких точка максимального накопичення змін також припадає на старший підлітковий вік. Таким чином, дослідження доводить статистично достовірне збільшення відсотку одиниць інформації, пов'язаних із «внутрішніми» індикаторами оцінювання концептуального змісту лексеми «Дорослість» (самостійність, відповідальність, досвід життя, наявність планів на майбутнє і цілей життя), форматування якої має зламним моментом $\left(\mathrm{d}_{\max }\right.$ накопичення змін) період старшого підліткового віку.

3 метою підтвердження значимості отриманих даних був використаний метод рангових кореляцій Спірмена (Rs), що дозволив уточнити напрямок і силу кореляційних зв'язків між ієрархіями ознак образу дорослості у віковій динаміці (табл. 2).

Аналіз даних матриці інтеркореляцій уточнює описані вище трансформації концептуального змісту лексеми «Дорослість» та 
ілюструє перехідний характер підліткового віку; суб'єктивні образи дорослості, створені респондентами молодшого і середнього підліткового віку, достовірно (при $\mathrm{p}<0,05 \mathrm{i} \mathrm{p}<0,01$ ) корелюють iз моделлю дитячого образу дорослості, а концепти старших підлітків та юнацтва - вже із дорослим баченням специфіки концептосфери на позначення феномену дорослості (із ранговим профілем студентства): $\mathrm{Rs}=0,85$ i $\mathrm{Rs}=0,8$ (при $\mathrm{p}<0,01$ ). Змінення вектору орієнтування у площинах досліджуваної концептосфери обумовлені, перш за все, збагаченням життєвого досвіду респондентів.

Таблиця 2. Матриця інтеркореляцій групових ієрархій у профілях образу дорослості респондентів

\begin{tabular}{|c|c|c|c|c|c|c|}
\hline $\begin{array}{l}\text { Вікові групи } \\
\text { респондентів }\end{array}$ & $\begin{array}{c}7-9 \\
\text { років } \\
(\mathrm{N}=57)\end{array}$ & $\begin{array}{c}\text { 10-11 } \\
\text { років } \\
(\mathrm{N}=296)\end{array}$ & $\begin{array}{c}12-13 \\
\text { років } \\
(\mathrm{N}=255)\end{array}$ & $\begin{array}{c}\text { 14-15 } \\
\text { років } \\
(\mathrm{N}=121)\end{array}$ & $\begin{array}{l}16-17 \\
\text { років } \\
(\mathrm{N}=60)\end{array}$ & $\begin{array}{l}20-27 \\
\text { років } \\
(\mathrm{N}=72)\end{array}$ \\
\hline $\begin{array}{l}\text { 7-9 років (дитяча модель } \\
\text { образу дорослості) }\end{array}$ & $\mathrm{x}$ & $0,89 * *$ & $0,72 * *$ & 0,19 & 0,28 & $-0,15$ \\
\hline 10-11 років & & $\mathrm{x}$ & $0,97 * *$ & 0,54 & 0,53 & 0,22 \\
\hline 12-13 років & & & $\mathrm{x}$ & $0,71 * *$ & $0,72 * *$ & 0,44 \\
\hline 14-15 років & & & & $\mathrm{x}$ & $0,94 * *$ & $0,85^{* *}$ \\
\hline 16-17 років & & & & & $\mathrm{x}$ & $0,8 * *$ \\
\hline $\begin{array}{l}\text { 20-27 років, студенти } \\
\text { (нормативна модель } \\
\text { дорослості) }\end{array}$ & & & & & & $\mathrm{x}$ \\
\hline
\end{tabular}

$* \mathrm{p}<0,05 \quad * * \mathrm{p}<0,01$

Примітка: Використано критичні значення коефіцієнта кореляції рангів

Означені тенденції вікової динаміки когнітивно-семантичної модернізації суб'єктивного образу дорослості у свідомості школярів дозволяють констатувати, що, при значній стійкості ядра концептосфери на позначення феномену дорослості в цілому, периферійні сегменти цієї системи (і зокрема - інтерпретаційний) змінюються у віковій динаміці. Досліджувана концептосфера не лише входить до ядра мовної свідомості школярів підлітковоюнацького віку, але й моделює особливу семантичну зону у семантичному просторі становлення мовної особистості.

Отримані результати суттєво доповнюють представлені науковою спільнотою матеріали щодо тенденцій концептуалізації індикаторів дорослішання (becoming an adult) молоді. У публікаціях американських (Arnett, 1997, 2007; Massoglia \& Uggen, 2010 ect.) та 
польських (Gurba, 2008, ect.) науковців доведено виражену сталість характеристик образу дорослості в групах респондентів підлітковоюнацького віку (15/16-18 років) та у когорті дорослих осіб. Серед атрибутивних ознак дорослості респонденти обох вибіркових сукупностей найменш важливими вважають такі «зовнішні» події, як досягнення певного віку, завершення навчання чи створення сім'ї; найбільш популярними категоріями позначення дорослості стали такі суб'єктивні властивості особистості як здатність приймати та виконувати нові соціальні ролі або брати на себе відповідальність за наслідки своїх дій. Іншими словами, ці дослідження підтверджують, що ранній юнацький вік (16-18 років) $є$ завершенням процесу концептуалізації суб'єктивного образу дорослості. Проте, згідно із представленими у даній статті результатами дослідження, основні трансформації суб'єктивного образу дорослості у семантичному просторі мовної особистості відбуваються в онтогенезі раніше - у період середнього (12-13 років) та старшого (14-15 років) етапів підліткового віку, який, власне, і має бути об'єктом корекційних та профілактичних інтервенцій на шляху категоризації конструктивної моделі дорослості у мовній свідомості підлітків.

\section{Висновки}

Осмислення проблеми концептуалізації суб'єктивного образу дорослості у семантичному просторі мовної особистості детермінує розуміння вимірів моделювання картини світу (що відображує когнітивно-семантичний контент усвідомлюваного світоустрою) у контекстуальності життєтворення як складний, багатоплановий процес трансформації особистісної ментальності суб'єкта дорослішання у системах мовної свідомості. Безперервно інтеріоризуючи інформаційні потоки й засвоюючи досвід, дитина модифікує їх у відповідні концепти, котрі логічно поєднуються у когнітивно-семантичному просторі концептосфери, означеної мовними знаками.

Зону потенційного розвитку особистості у період дорослішання визначає концептосфера на позначення феномену дорослості, в межах якої моделюються стратегічні зразки дорослішання. Особливо актуальною проблема осмислення індикаторів дорослості $€$ у 
підлітково-юнацькому віці, протягом якого концептосфера дорослості $\epsilon$ відображенням вкрай необхідних суб'єктам дорослішання внутрішніх якостей і $є$ тією суб'єктивною компонентою розвитку, котра стає чинником зміни соціальної ситуації. У форматуванні суб'єктивного образу дорослості школярами підлітково-юнацького віку відбувається перехід від емпіричного виявлення та усвідомлення переважно «зовнішніх» атрибутів дорослості до узагальнення внутрішніх релевантних підсистем дорослості, що задовольняють онтогенетичним вимогам до формування особистісних конструктів в умовах сучасного соціокультурного середовища і складають ядерну частину досліджуваного концепту.

Результати емпіричного дослідження доводять, що основним періодом концептуалізації суб'єктивного образу дорослості у семантичному просторі мовної особистості є середній (12-13 років) та старший (14-15 років) підлітковий вік. Аналіз змістової наповненості показників семантичного поля концептів Дорослий i Дорослішати (структурних елементів концептосфери на позначення феномену дорослості) дозволив виявити одиниці квантифікації семантичного поля досліджуваної концептосфери і підтвердити гіпотезу емпіричного дослідження щодо значущості відмінностей концептуалізації суб'єктивного образу дорослості у мовній свідомості суб'єктів дорослішання різного віку.

Представлені у статті результати дослідження питань концептуалізації у віковій динаміці мовної особистості суб'єктивного образу дорослості, за нашим переконанням, сприятимуть вирішенню широкого спектру теоретичних i практичних задач, пов'язаних iз розумінням динамічного контексту семантики психологічного супроводу дорослішання.

Перспективи дослідження ми вбачаємо у дослідженні семантичних особливостей «образу власних змін» суб'єктів дорослішання, що дозволить вибудувати орієнтири роботи фахівцівпсихологів зі школярами у контексті попередження труднощів розвитку дорослості в цілому.

\section{Література}

Андреева, А.Д. (2018). Особенности субъективного образа детства у родителей учащихся первых и пятых классов школ разного типа. Теоретическая $u$ экспериментальная психология, 11 (3), 6-20. 
Кониептуалізація суб’єктивного образу дорослості...

Білодід, І.К. (Ред.). (1971). Словник української мови (Т. 1-11). (Т. 2). П.П. Доценко \& Л.А. Юрчук (Ред.). Київ: Наукова думка.

Блох, М.Я. (2010). Концепт и картина мира в философии языка. Пространство и время, 1, 37-40.

Воркачев, С.Г. (2001). Лингвокультурология, языковая личность, концепт: становление антропоцентрической парадигмы в языкознании. Филологические науки, 1, 64-72.

Воркачев, С.Г. (2014). Лингвокультурная концептология и ее терминосистема (продолжение дискуссии). Политическая лингвистика, 3 (49), 12-20.

Выготский, Л.С. (1984). Педология подростка: Проблема возраста. Д.Б. Эльконин (Ред.), Собрание сочинений (Т. 1-6). (Т. 4, с. 5-269). Москва: Педагогика.

Гоменюк, О.О. (2015). Концептосфери флори і фауни в українській дитячій прозі Є. Гуцола і М. Вінграновського. Дис. канд. філол. наук. Тернопіль.

Городецька, О.В. (2002). Національно марковані концепти в британській мовній картині світу ХX ст. Дис. канд. філол. наук. Київ.

Жайворонок, В.В. (2004). Етнолінгвістика в колі суміжних наук. Мовознавство, $5(6), 23-35$.

Зоріна, В.I. (2017). Ідеальний образ дорослого як чинник особистісного розвитку підлітка. Автореф. дис. канд. психол. наук. Київ.

Калмикова, Л.О. (2003). Розвиток значення і смислу слів в онтогенезі. Збірник наукових праџь Інституту психологї імені Г.С. Костюка АПН Украӥни, 5 (1), 96-104.

Лисиченко, Л.А. (2009). Лексико-семантичний вимір мовної картини світу. Харків: Основа.

Мартинюк, А.П. (2006). Когнітивно-дискурсивний напрям дослідження концептів у сучасній лінгвістиці. Проблеми романо-германської філології (с. 92-107). Ужгород: Ліра.

Петровский, А.В., \& Ярошевский, М.Г. (Ред). (1998). Краткий психологический словарь. Ростов-на-Дону: Феникс.

Полюжин, М.M. (2005). Концептуальна система як базове поняття когнітивної семантики й теорії мовної особистості. Проблеми романо-германської філології (с. 5-20). Ужгород: Ліра.

Постовалова, В.И. (1988). Картина мира в жизнедеятельности человека. Б.А. Серебренников (Отв. ред.), Человеческий фактор в языке: Язык и картина мира (с. 8-69). Москва: Наука.

Протасова, Е., Родина, Н., \& Васюкова, Н. (2011). Эффективная речь взрослого. Т.А. Круглякова (Отв. ред.), Онтолингвистика - наука XXI века: материаль международной конференции, посвященной 20-летию кафедры детской речи РГПУ им. А.И. Гериена (2. Санкт-Петербург, 4-6 мая, 2011), (с. 604-606). Санкт-Петербург: Златоуст.

Радзієвська, Т.В. (2010). Нариси з кониептуального аналізу та лінгвістики тексту: Текст - сочіум - культура - мовна особистість. Київ: ДП «Інформ.-аналіт. агенство».

Рогожникова, Т.М. (2008). Человек как академия семантики: динамические аспекты значения слова. В.А. Пищальникова (Ред.), Языковое бытие человека и этноса (Березинские чтения). (Вып. 14, с. 209-212). Москва: МГЭИ; ИНИОН РАН; МГЛУ.

Токарева, Н.М. (2015). Психологія комунікативного моделювання особистісних конструктів у підлітковому віці. Дис. д-ра психол. наук. Київ. 
Цейтлин, С.Н. (2018). Онтолингвистика в пути. Известия РГПУ им. А.И. Гериена, 189, 12-22.

Чернобровкина, С.В. (2015). Личностное взросление современных студентов: специфика и факторы образа и самооценки взрослости. Вестник Омского университета. Серия «Психология», 2, 24-29.

Arnett, J.J. (1997). Young people's conceptions of the transition to adulthood. Youth \& Society, 29 (1), 3-23. https://doi.org/10.1177/0044118X97029001001

Arnett, J.J. (2007). Emerging Adulthood: What Is It, and What Is It Good For? Child Development Perspectives, 1 (2), 68-73. https://doi.org/10.1111/j.17508606.2007.00016.x

Evans, V. (2006). Lexical Concepts, Cognitive Models and Meaning-Construction. Cognitive Linguistics, 17 (4), 491-534. https://doi.org/10.1515/COG.2006.016

Gurba, E. (2008). The Attributes of Adulthood Recognised by Adolescents and Adults. Polish Psychological Bulletin, 39 (3), 129-137. https://doi.org/10.2478/v10059008-0020-9

Kharchenko, N.V. (2017). Language personality of a preschool child: features of development in the process of listening. Psiholingvistika - Psycholinguistics 21 (1), 171-185.

Massoglia, M., \& Uggen, Ch. (2010). Settling Down and Aging Out: Toward an Interactionist Theory of Desistance and the Transition to Adulthood. American Journal of Sociology, 116 (2), 543-582. https://doi.org/10.1086/653835

Nelson, K. (1973). Structure and strategy in learning to talk. Monographs of the society for research in child development (Serial 149). (Vol. 38 (3-4), pp. 3-21). Wiley.

Taylor, J.R. (2003). Linguistic Categorization ( $3^{\text {rd }}$ ed.). Oxford: Oxsford University Press.

Shamne, A.V. (2013). The conceptual model of psychosocial development in the period of adolescence. Science and Education a New Dimension: Pedagogy and Psychology, 3, 165-169.

Wierzbicka, A. (1992). Semantics, Culture and Cognition, Universal Human Concepts in Culture - Specific Configuration. New York; Oxford: OUP.

\section{References}

Andreeva, A.D. (2018). Osobennosti subektivnogo obraza detstva u roditelej uchashihsya pervyh i pyatyh klassov shkol raznogo tipa [Peculiarities of the subjective image of childhood in parents of schoolchilds of the first and fifth grades of schools of various types]. Teoreticheskaya $i$ eksperimentalnaya psihologiya - Theoretical and Experimental Psychology, 11 (3), 6-20 [in Russian].

Bilodid, I.K. (Ed.). (1971). Slovnyk ukrainskoi movy [Dictionary of the Ukrainian language] (Vols. 1-11). (Vol. 2). Kyiv: Naukova dumka [in Ukrainian].

Bloh, M.Ja. (2010). Koncept i kartina mira v filosofii jazyka [Concept and picture of the world in the philosophy of language]. Prostranstvo $i$ vremja - Space and Time, 1, 37-40 [in Russian].

Vorkachev, S.G. (2001). Lingvokulturologija, jazykovaja lichnost, koncept: stanovlenie antropocentricheskoj paradigmy $\mathrm{v}$ jazykoznanii [Linguoculturology, linguistic personality, concept: the formation of an anthropocentric paradigm in linguistics]. Filologicheskie nauki - Philological Sciences, 1, 64-72 [in Russian]. 
Кониептуалізація суб’єктивного образу дорослості...

Vorkachev, S.G. (2014). Lingvokulturnaya konceptologiya i ee terminosistema (prodolzhenie diskussii) [Linguocultural conceptology and its terminology (continued discussion)]. Politicheskaja lingvistika - Political Linguistics, 3 (49), 12-20 [in Russian].

Vygotskij, L.S. (1984). Pedologiya podrostka: Problema vozrasta [Adolescent Pedology: The Problem of Age]. In D.B. Elkonin (Ed.), Sobranie sochineniy - Collected Works (Vols. 1-6). (Vol. 4, pp. 5-269). Moscow: Pedagogika [in Russian].

Gomenjuk, O.O. (2015). Konceptosferi flori i fauni v ukrayinskij dityachij prozi Ye. Gucola i M. Vingranovskogo [Concepts of flora and fauna in Ukrainian children's prose by E. Gutsol and M. Vingranovsky]. Candidate's thesis. Ternopil [in Ukrainian].

Gorodecka, O.V. (2002). Nacionalno markovani koncepty v brytanskij movnij kartyni svitu XX st. [Nationally labeled concepts in the British linguistic picture of the $\mathrm{XX}$ century]. Candidate's thesis. Kyiv [in Ukrainian].

Zhajvoronok, V.V. (2004). Etnolingvistyka v koli sumizhnyh nauk [Ethnolinguistics in the circle of related sciences]. Movoznavstvo - Linguistics, 5 (6), 23-35 [in Ukrainian].

Zorina, V.I. (2017). Idealnyj obraz doroslogo jak chynnyk osobystisnogo rozvytku pidlitka [The ideal image of an adult as a factor in the personal development of a teenager]. Extended abstract of Candidate's thesis. Kyiv [in Ukrainian].

Kalmykova, L.O. (2003). Rozvytok znachennja i smyslu sliv v ontogenezi [Development of meaning and meaning of words in ontogeny]. Zbirnyk naukovyh prac Instytutu psyhologii imeni G.S. Kostjuka APN Ukrainy - Collection of scientific works of the Institute of Psychology named after G.S. Kostyuk of the National Academy of Sciences of Ukraine, 5 (1), 96-104). Kyiv [in Ukrainian].

Lysychenko, L.A. (2009). Leksyko-semantychnyj vymir movnoi kartyny svitu [The Lexical-Semantic Dimension of the Linguistic Picture of the World]. Harkiv: Osnova [in Ukrainian].

Martynjuk, A.P. (2006). Kognityvno-dyskursyvnyj naprjam doslidzhennja konceptiv $\mathrm{u}$ suchasnij lingvistyci [Cognitive-discursive direction of concepts research in modern linguistics]. Problemy romano-germanskoi filologii - Problems of Romano-Germanic Philology (pp. 92-107). Uzhgorod: Lira [in Ukrainian].

Petrovskij, A.V., \& Jaroshevskij, M.G. (Ed.). (1998). Kratkij psihologicheskij slovar [Brief Psychological Dictionary]. Rostov-na-Donu: Feniks [in Russian].

Poljuzhyn, M.M. (2005). Konceptualna systema jak bazove ponjattja kognityvnoi semantyky $\mathrm{j}$ teorii movnoi osobystosti [The conceptual system as a basic concept of cognitive semantics and linguistic personality theory]. Problemy romanogermanskoi filologii - Problems of Romano-Germanic Philology (pp. 5-20). Uzhgorod: Lira [in Ukrainian].

Postovalova, V.I. (1988). Kartina mira v zhiznedejatelnosti cheloveka [The picture of the world in human life]. In B.A. Serebrennikov (Ed), Chelovecheskij faktor $v$ jazyke: Jazyk $i$ kartina mira - The Human Factor in Language: Language and Worldview (pp. 8-69). Moscow: Nauka [in Russian].

Protasova, E., Rodina, N., \& Vasyukova, N. (2011). Effektivnaya rech vzroslogo [Effective Adult Speech]. In T.A. Kruglyakova (Ed.), Proceedings from: Mezhdunarodnaja konferenciya, posvjashhennaya 20-letiju kafedry detskoj rechi RGPU im. A.I. Gercena «Ontolingvistika - nauka XXI veka» - The International conference dedicated to the 20th anniversary of the department of children's speech at Russian State Pedagogical University named after A.I. Herzen 
«Ontolinguistics is a science of the 21 st century» (Sant-Peterburg, May, 4-6, 2011), (pp. 604-606). Sant-Peterburg: Zlatoust [in Russian].

Radzijevska, T.V. (2010). Narysy z konceptualnogo analizu ta lingvistyky tekstu: Tekst - socium - kultura - movna osobystist [Essays on Conceptual Analysis and Linguistics of the Text: Text - Society - Culture - Linguistic Personality]. Kyiv: DP «Inform.-analit. agenstvo» [in Ukrainian].

Rogozhnikova, T.M. (2008). Chelovek kak akademija semantiki: dinamicheskie aspekty znachenija slova [Man as an academy of semantics: dynamic aspects of the meaning of a word]. In V.A. Pishhalnikova (Ed.), Jazykovoe bytie cheloveka $i$ jetnosa (Berezinskie chtenija) - Linguistic Being of Man and Ethnos (Berezinsky readings). (Vol. 14, pp. 209-212). Moscow: MGJeI; INION RAN; MGLU [in Russian].

Tokareva, N.M. (2015). Psyhologija komunikatyvnogo modeljuvannja osobystisnyh konstruktiv u pidlitkovomu vici [Psychology of communicative modeling of personality constructs in adolescence]. Doctor's thesis. Kyiv [in Ukrainian].

Tseytlin, S.N. (2018). Ontolingvistika v puti [Ontolinguistics on the way]. Izvestiya Rossijskogo gosudarstvennogo pedagogicheskogo universiteta im. A.I. GertsenaNews of the Russian State Pedagogical University named after A.I. Herzen, 189, 12-22 [in Russian].

Chernobrovkina, S.V. (2015). Lichnostnoe vzroslenie sovremennyh studentov: specifika i faktory obraza i samoocenki vzroslosti [Personal maturation of modern students: specificity and factors of the image and self-esteem of adulthood]. Vestnik Omskogo universiteta. Serija "Psihologija» - Bulletin of Omsk University. Series "Psychology», 2, 24-29 [in Russian].

Arnett, J.J. (1997). Young people's conceptions of the transition to adulthood. Youth \& Society, 29 (1), 3-23. https://doi.org/10.1177/0044118X97029001001

Arnett, J.J. (2007). Emerging Adulthood: What Is It, and What Is It Good For? Child Development Perspectives, 1 (2), 68-73. https://doi.org/10.1111/j.17508606.2007.00016.x

Evans, V. (2006). Lexical Concepts, Cognitive Models and Meaning-Construction. Cognitive Linguistics, 17 (4), 491-534. https://doi.org/10.1515/COG.2006.016

Gurba, E. (2008). The Attributes of Adulthood Recognised by Adolescents and Adults. Polish Psychological Bulletin, 39 (3), 129-137. https://doi.org/10.2478/v10059008-0020-9

Kharchenko, N.V. (2017). Language personality of a preschool child: features of development in the process of listening. Psiholingvistika - Psycholinguistics 21 (1), 171-185.

Massoglia, M., \& Uggen, Ch. (2010). Settling Down and Aging Out: Toward an Interactionist Theory of Desistance and the Transition to Adulthood. American Journal of Sociology, 116 (2), 543-582. https://doi.org/10.1086/653835

Nelson, K. (1973). Structure and strategy in learning to talk. Monographs of the society for research in child development (Serial 149). (Vol. 38 (3-4), pp. 3-21). Wiley.

Taylor, J.R. (2003). Linguistic Categorization $\quad\left(3^{\text {rd }}\right.$ ed. $) . \quad$ Oxford: Oxsford University Press.

Shamne, A.V. (2013). The conceptual model of psychosocial development in the period of adolescence. Science and Education a New Dimension: Pedagogy and Psychology, 3, 165-169.

Wierzbicka, A. (1992). Semantics, Culture and Cognition, Universal Human Concepts in Culture - Specific Configuration. New York; Oxford: OUP. 
Кониептуалізація суб’єктивного образу дорослості...

\section{АНОТАЦІЯ}

Вступ. Стаття присвячена аналізу проблеми когнітивно-семантичного моделювання суб'єктивного образу дорослості школярами підлітковоюнацького віку у сучасному сочіокультурному просторі. Авторами доведено, що логіко-смислові конструкти мовної картини світу експлікують соціолект суб'єктів мовлення і утворюють концептуальний простір ментального континууму, що $\epsilon$ особливо актуальним для переосмислення семантичних індикаторів особистісного становлення людини у період дорослішання. Образ дорослості інтерпретується авторами як максимально персоналізована системна структура, котра відображує уявлення суб'єктів мовної свідомості про ідеального себе у часовій перспективі.

Прочедура дослідження. Процедура дослідження передбачала використання методів концептуального аналізу, аналізу словникових дефінічій, контентаналізу. За результатами вивчення 4207 текстових фррагментів і відповідей респондентів були виділені одиниці квантифікації семантичного поля досліджуваної концептосфери, ядро (семантичну константу) й периферійну частину (ії інформаційно-змістовий та інтерпретаційний сегменти).

Результати. Емпірично були уточнені характеристики лінгвалізації концептосфери на позначення френомену дорослості у семантичному просторі мовної особистості, виявлені психолінгвістичні особливості мовної об'єктивації концептів Дорослий $і$ Дорослішати у свідомості суб'єктів дорослішання, означені тенденції вікової динаміки когнітивно-семантичної природи концептосрери дорослості у свідомості школярів. Констатовано, що у форматуванні суб'єктивного образу дорослості школярами підлітково-юнацького віку відбувається перехід від емпіричного виявлення та усвідомлення переважно “зовнішніх» атрибутів дорослості до узагальнення внутрішніх релевантних підсистем оцінювання світу, себе та інших людей (передусім, дорослих). Статистично підтверджено, що основні трансформації суб'єктивного образу дорослості у семантичному просторі мовної особистості відбуваються у підлітковому віці, який і має бути об'єктом корекційних та профрілактичних інтервенцій у динамічному контексті психологічного супроводу дорослішання.

Висновки. Отримані результати суттєво доповнюють представлені науковою спільнотою матеріали щодо тенденцій концептуалізації індикаторів дорослішання сучасної молоді.

Ключові слова: образ дорослості, мовна картина світу, мовна особистість, підлітково-юнацький вік, концептосрера, семантико-когнітивна модель, логікосмисловий конструкт, семантичне поле. 
Токарева Наталья \& Шамне Анжелика. Концептуализация субъективного образа взрослости в семантическом пространстве языковой личности

\begin{abstract}
АННОТАЦИЯ
Вступление. Статья посвящена анализу проблемы когнитивносемантичного моделирования субъективного образа взрослости школьниками подростково-юношеского возраста в современном социокультурном пространстве. Авторами доказано, что логико-смысловые конструкты языковой картины мира эксплицируют сочиолект субъектов речи и образуют концептуальное пространство ментального континуума, что особенно актуально для переосмысления семантических индикаторов личностного становления человека в период взросления. Образ взрослости интерпретируется авторами как максимально персонализированная системная структура, отображающая представление субъектов языкового сознания о себе идеальном во временной перспективе.
\end{abstract}

Процедура исследования. Процедура исследования предусматривала использование методов концептуального анализа, анализа словарных дефиниций, контент-анализа. По результатам изучения 4207 текстовых фрагментов и ответов респондентов были выделены единицы квантификации семантического поля исследуемой концептосферы, ядро (семантическая константа) и перифрерийная часть (ее информационно-содержательный и интерпретационный сегменты).

Результаты. Эмпирически были уточнены характеристики лингвализации концептосферы для обозначения феномена взрослости в семантическом пространстве языковой личности, выявлены психолингвистические особенности языковой объективации концептов Взрослый и Взрослеть в сознании субъектов взросления, очерчены тенденции возрастной динамики когнитивно-семантической природы концептосреры взрослости в сознании школьников. Констатировано, что при форматировании субъективного образа взрослости школьниками подростково-юношеского возраста происходит переход от эмпирического выявления и осознания преимущественно "внешних» атрибутов взрослости к обобщению внутренних релевантных подсистем оценивания мира, себя и других людей (прежде всего, взрослых). Статистически подтверждено, что основные трансрормации субъективного образа взрослости в семантическом пространстве языковой личности происходят в подростковом возрасте, который и должен быть объектом коррекционных и профилактических интервенций в динамическом контексте психологического сопровождения взросления.

Выводы. Полученные результаты существенно дополняют представленные научным сообществом материалы о тенденциях концептуализации индикаторов взросления современной молодежи.

Ключевые слова: образ взрослости, языковая картина мира, языковая личность, подростково-юношеский возраст, концептосфера, семантикокогнитивная модель, логико-смысловой конструкт, семантическое поле. 